\title{
MICROSTRUCTURE AND PROPERTIES OF THE HIGH-TEMPERATURE (HAZ) OF THERMO-MECHANICALLY TREATED S700MC HIGH-YIELD-STRENGTH STEEL
}

\author{
MIKROSTRUKTURA IN LASTNOSTI VISOKO TEMPERATURNEGA \\ OBMOČJA ZVARA (HAZ) TERMO-MEHANSKO OBDELANEGA JEKLA \\ S700MC Z VISOKO MEJO PLASTIČNOSTI
}

\author{
Jacek Górka \\ Silesian University of Technology, Konarskiego Street 18a, 44-100 Gliwice, Poland \\ jacek.gorka@polsl.pl \\ Prejem rokopisa - received: 2015-06-18; sprejem za objavo - accepted for publication: 2015-07-17
}

doi:10.17222/mit.2015.123

\begin{abstract}
The aim of the study was to determine the properties and microstructure of the high-temperature heat affected zone (HAZ) of S700MC steel heated to a temperature of $1250{ }^{\circ} \mathrm{C}$ and cooled at different speeds. The simulation of the thermal cycles was performed using a welding thermal cycles simulator. Samples with a cross-section $10 \mathrm{~mm} \times 10 \mathrm{~mm} \times 55 \mathrm{~mm}$ were submitted to metallographic analysis, impact tests, hardness measurements and tensile tests. Welding thermal cycles with cooling times $t_{8 / 5}=$ $\left(3,5,10,15,30,60\right.$ and 120) $\mathrm{s}$ and a maximum temperature cycle temperature of $T_{\max }=1250{ }^{\circ} \mathrm{C}$ were used. The welding thermal thermomechanical processing cycles differ significantly, especially with high rates of heating and cooling in the SWC, short time holding at the maximum temperature and frequent overlap of two or more cycles during the multi-layer welding. One of the elements in the evaluation of steel weldability is the analysis of the austenite phase transformation during cooling. Steel hardness tests on simulated HAZ regions cooling times increasing from $3 \mathrm{~s}$ to $120 \mathrm{~s}$, showed reductions by approximately 40 $\mathrm{HV}$, while, regardless of the length of the cooling time $t_{8 / 5}$, the impact resistance was very low, at the level of a few $\mathrm{J} / \mathrm{cm}^{2}$. The tensile strength, hardness and toughness indicates a secondary role of austenite in the control of welded joints transformation strength and plastic properties, the analysis of the $\gamma-\alpha$ phase transition not shown to be a reliable basis for assessment of the weldability of this steel group.

Keywords: TMCP steel, welding thermal cycles, HAZ, high yield strength, impact resistance
\end{abstract}

Namen študije je bil določiti lastnosti in mikrostrukturo visokotemperaturne toplotno vplivanega območja zvara (HAZ) v jeklu S700MC, segretem na temperaturo $1250{ }^{\circ} \mathrm{C}$ in ohlajenem pri različnih hitrostih. Simulacija procesa toplotnih ciklov je bila izvedena z uporabo simulatorja toplotnih ciklov pri varjenju. Vzorci s presekom $10 \mathrm{~mm} \times 10 \mathrm{~mm} \times 55 \mathrm{~mm}$ so bili metalografsko pregledani, izveden je bil udarni preizkus, izmerjena je bila trdota in izvedeni so bili natezni preizkusi. Uporabljeni so bili toplotni cikli pri varjenju s časi ohlajanja $t_{8 / 5}=(3,5,10,15,30,60$ in 120) $\mathrm{s}$ in maksimalna temperatura toplotnega cikla je bila $T_{\max }=1250^{\circ} \mathrm{C}$. Pri varjenju se cikli varilno termičnega in termomehanskega procesiranja precej razlikujejo, predvsem pri veliki hitrosti ogrevanja in ohlajanja v SWC, kratkotrajnem zadržanju na maksimalni temperaturi in pogostem prekrivanju enega ali več ciklov pri večplastnih zvarih. Eden od elementov pri ocenjevanju varivosti jekla, je analiza premene avstenita med ohlajanjem. Pri preizkusih trdote simuliranih HAZ področij, se le ta, s povečanjem časa ohlajanja od $3 \mathrm{~s}$ na $120 \mathrm{~s}$, zmanjša za okrog $40 \mathrm{HV}$, medtem ko je žilavost zelo nizka in na nivoju nekaj $\mathrm{J} / \mathrm{cm}^{2}$ ne glede na čas ohlajanja $t_{8 / 5}$. Natezna trdnost, trdota in žilavost kažejo drugotno vlogo pri kontroli trdnosti in plastičnosti transformiranega avstenita zvarjenih spojev. Analiza faznega prehoda $\gamma-\alpha$ ni zanesljiva osnova za ugotavljanje varljivosti te vrste jekla.

Ključne besede: TMCP jeklo, toplotni cikel pri varjenju, HAZ, visoka meja plastičnosti, odpornost na udarce

\section{INTRODUCTION}

Steels produced using thermomechanical treatment are characterised by a lower carbon equivalent than steels of the same yield point treated to normalisation annealing. ${ }^{1}$ Also for yield points above $550 \mathrm{MPa}$, steels subjected to thermomechanical rolling with accelerated cooling and tempering are characterised by a lower carbon equivalent than toughened steels. ${ }^{2-5}$ Due to the significantly lower carbon equivalent, thermomechanicaly treated steels should have significantly better weldability in comparison to normalised or toughened steels of a similar yield point. The alloying microagents of S700MC steel, i.e. niobium, vanadium and titanium are strongly carbide and nitride-forming. If dissolved in the HAZ, they increase HAZ hardenability and steel hard- ness after cooling. This phenomenon is considered disadvantageous. However, on the other hand, carbides and carbonitride precipitates of $\mathrm{Nb}, \mathrm{V}$, and $\mathrm{Ti}$ effectively impede grain growth and significantly restrict the width of the coarse-grained area of the HAZ. ${ }^{6-8}$ The HAZ ductility is significantly improved by $\mathrm{Ti}_{2} \mathrm{O}_{3}$ particles, which are more stable than TiN particles and insoluble even at higher temperatures and act as nucleii by the nucleation of fine-lamellar ferrite. ${ }^{9-11}$ Fine-lamellar ferrite within austenite grains increases the HAZ ductility. The HAZ microstructure of a multi-run welded joint depends on the chemical composition of the steel, heat source intensity and the number of runs. Both cooling rate and heat input significantly affect the HAZ weld microstructure. By cooling welds of thermomechanically treated steels, niobium, vanadium and titanium precipitate as carbides 
and carbonitrides. During cooling, these microagents precipitate in the form of carbides and carbonitrides. The amount of precipitates depends on the cooling rate. The faster the cooling, the more microagents remain in solution. A similar situation is observed in the Heat Affected Zone. The amount of microelements in solution significantly affects phase transformation during cooling and changes the properties after subsequent heat treatments. ${ }^{12}$ This increases the content of microstructural components formed by diffusionless and indirect (bainitic) transformations. Such microstructures are the primary reason for decreased toughness, particularly in wide HAZ. This effect is even greater in welding with high linear energy and prolonged cooling times $t_{8 / 5}$. In the case of high cooling rates, a typical HAZ structure in thermomechanically processes steels contains lower bainite characterised by satisfactory brittle cracking resistance. A high welding heat input extends the HAZ, holds it at high temperatures and reduces the cooling rate, leading to austenite grain growth and, consequently, particularly near the fusion line, the formation of a microstructure characterised by lower plastic properties. In such case, the HAZ structure is dominated by upper bainite as well as by delta and side-lamellar ferrite. ${ }^{13,14}$

\section{EXPERIMENTAL PROCEDURE}

HAZ areas simulated in S700 MC steel (Table 1 and Figure 1) heated up to $1250{ }^{\circ} \mathrm{C}$ and cooled at various rates, were used for testing. The thermal cycles were performed with a welding thermal cycle simulator on specimens with a cross-section of $10 \mathrm{~mm} \times 10 \mathrm{~mm} \times 55$ $\mathrm{mm}$. The specimens were then used for metallographic examination, impact strength tests, hardness measurements and tensile tests.

Table 1: The chemical composition of S700 MC steel Tabela 1: Resnična kemijska sestava jekla S700 MC

\begin{tabular}{|c|c|c|c|c|c|c|c|c|c|c|}
\hline \multicolumn{10}{|c|}{ Chemical composition, \% } \\
\hline $\mathrm{C}$ & $\mathrm{Mn}$ & $\mathrm{Si}$ & $\mathrm{S}$ & $\mathrm{P}$ & $\mathrm{Al}$ & $\mathrm{Nb}$ & $\mathrm{Ti}$ & $\mathrm{V}$ & $\mathrm{N}^{*}$ & $\mathrm{C}_{\mathrm{e}}$ \\
\hline 0,056 & 1,68 & 0,16 & 0,005 & 0,01 & $0,0270,044$ & 0,12 & 0,006 & 72 & 0,33 \\
\hline
\end{tabular}

* - N: the amount given in ppm, the nitrogen was measured using the high temperature extraction method

The specimens were submitted to welding thermal cycles and cooling times $t_{8 / 5}=(3,5,10,15,30,60$ and 120) s, with the thermal cycle maximum temperature $T_{\max }=1250{ }^{\circ} \mathrm{C}$. The thermal cycle maximum temperature was read from a diagram recorded by means of a PC. In Table 2 (pre-set and measured) parameters of test steel thermal cycles are presented.

After the simulation, the specimens were submitted in accordance with the standard PN-EN ISO 9015-1 to Charpy V impact tests using a ZWICK/ROELL RKP 450 at a temperature of $-30{ }^{\circ} \mathrm{C}$, to metallographic examination on a NIKON ECLIPSE MA100 light microscope, and to Vickers hardness tests with a $9.81 \mathrm{~N}$ (HV1) load using a WILSON WOLPERT MICRO-VICKERS

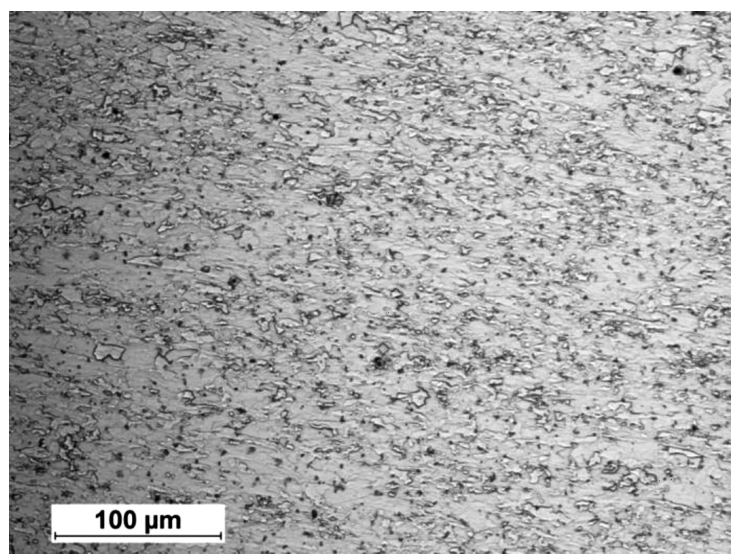

Figure 1: Microstructure of bainitic-ferritic steel S700MC with visible traces of plastic deformation

Slika 1: Mikrostruktura bainitno-feritnega jekla S700MC, z vidnimi sledovi plastične deformacije

401MVD hardness tester. Each specimen underwent 7 measurements, the two extreme values (minimum and maximum) rejected and the remaining five values averaged. The mechanical and plastic properties of round specimens were determined according to PN-EN 10002-1, using the MTS Insight testing machine.

Table 2: Input parameters and simulated thermal cycles of S700MC steel

Tabela 2: Vhodni parametri in simulirani toplotni cikli pri jeklu S700MC

\begin{tabular}{|c|c|c|c|}
\hline \multirow[t]{2}{*}{ No. } & \multirow{2}{*}{$\begin{array}{l}\text { Types of } \\
\text { cycles }\end{array}$} & \multicolumn{2}{|c|}{$\begin{array}{c}\text { Maximum temperature of } \\
\text { cycles } \mathrm{T}_{\max },{ }^{\circ} \mathrm{C}\end{array}$} \\
\hline & & Set & Real \\
\hline 1 & \multirow{3}{*}{3} & 1250 & 1223 \\
\hline 2 & & 1250 & 1215 \\
\hline 3 & & 1250 & 1247 \\
\hline 4 & \multirow{3}{*}{5} & 1250 & 1231 \\
\hline 5 & & 1250 & 1234 \\
\hline 6 & & 1250 & 1217 \\
\hline 7 & \multirow{3}{*}{10} & 1250 & 1250 \\
\hline 8 & & 1250 & 1246 \\
\hline 9 & & 1250 & 1243 \\
\hline 10 & \multirow{3}{*}{15} & 1250 & 1257 \\
\hline 11 & & 1250 & 1262 \\
\hline 12 & & 1250 & 1255 \\
\hline 13 & \multirow{3}{*}{30} & 1250 & 1254 \\
\hline 14 & & 1250 & 1261 \\
\hline 15 & & 1250 & 1255 \\
\hline 16 & \multirow{3}{*}{60} & 1250 & 1262 \\
\hline 17 & & 1250 & 1258 \\
\hline 18 & & 1250 & 1265 \\
\hline 19 & \multirow{3}{*}{120} & 1250 & 1253 \\
\hline 20 & & 1250 & 1264 \\
\hline 21 & & 1250 & 1246 \\
\hline
\end{tabular}

\section{RESULTS AND DISCUSSION}

Previous tests of simulated HAZ areas heated to various maximum temperatures revealed that the HAZ were characterised by mechanical and plastic properties 
J. GÓRKA: MICROSTRUCTURE AND PROPERTIES OF THE HIGH-TEMPERATURE (HAZ) ...

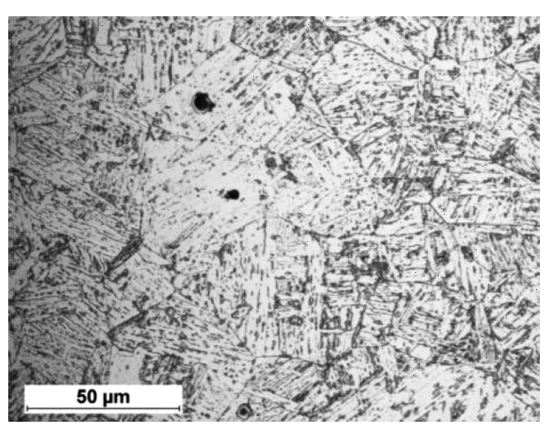

Cooling time $t_{8 / 5}=3 \mathrm{~s}$

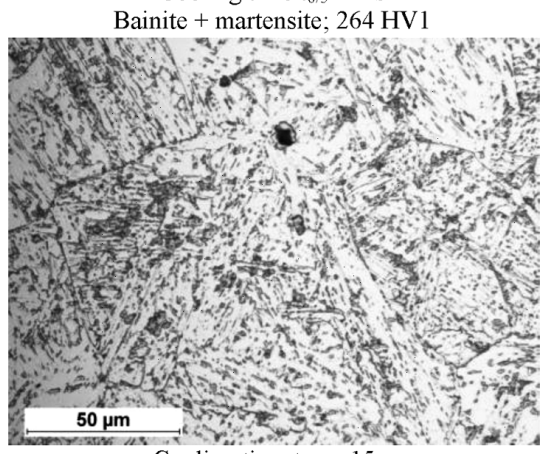

Cooling time $\mathrm{t}_{8 / 5}=15 \mathrm{~s}$

Bainite + ferrite; $249 \mathrm{HV} 1$

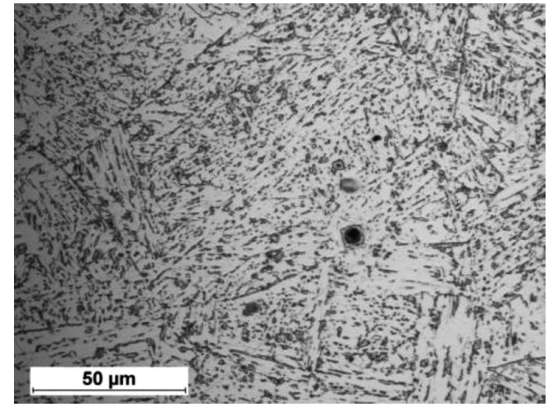

Cooling time $t_{855}=5 \mathrm{~s}$ Bainite + martensite; $258 \mathrm{HV} 1$

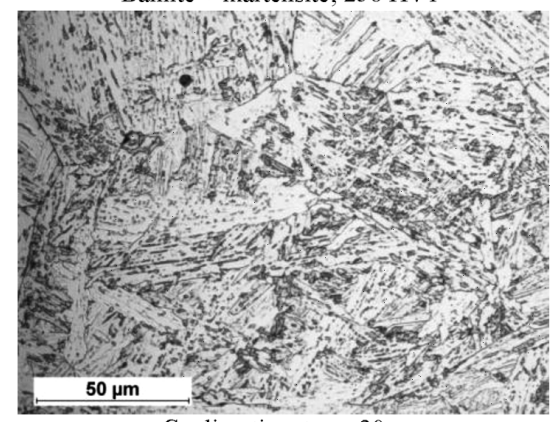

Cooling time $t_{8 / 5}=30 \mathrm{~s}$

Bainite + ferrite; $234 \mathrm{HVl}$

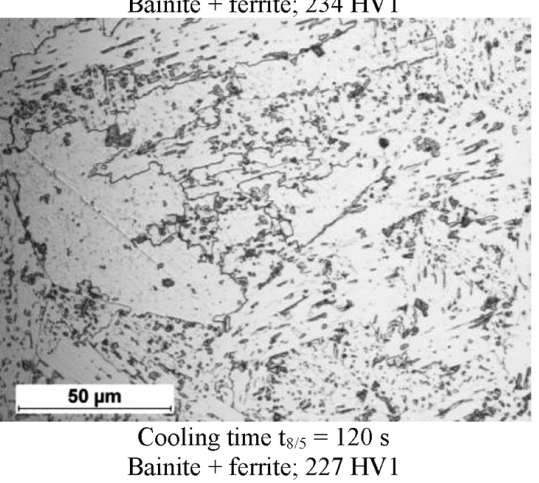

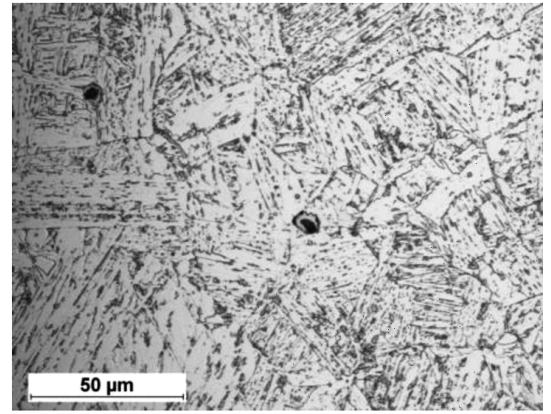

Cooling time $\mathrm{t}_{85}=10 \mathrm{~s}$

Bainite; $250 \mathrm{HV} 1$

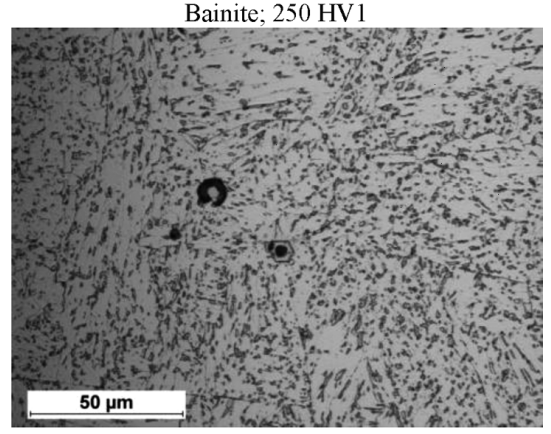

Cooling time $\mathrm{t}_{8 / 5}=60 \mathrm{~s}$

Bainite + ferrite; $237 \mathrm{HV} 1$

Figure 2: S700MC steel microstructure as a function of the cooling time $t_{8 / 5}$

Slika 2: Mikrostruktura jekla S700MC v odvisnosti od časa ohlajanja $t_{8 / 5}$

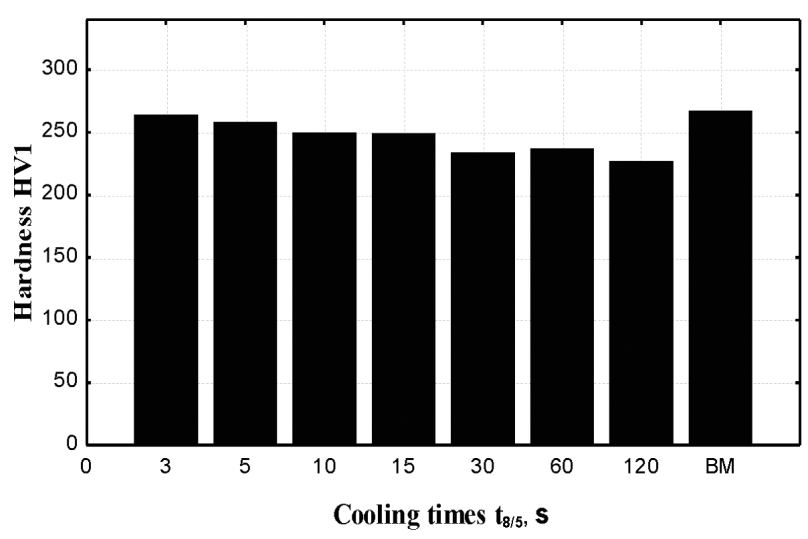

Figure 3: Hardness of simulated HAZ HV1 S700MC steel, cycle temperature $1250{ }^{\circ} \mathrm{C}$

Slika 3: Simulirana trdota HV1 v HAZ jekla S700MC, temperatura cikla $1250{ }^{\circ} \mathrm{C}$

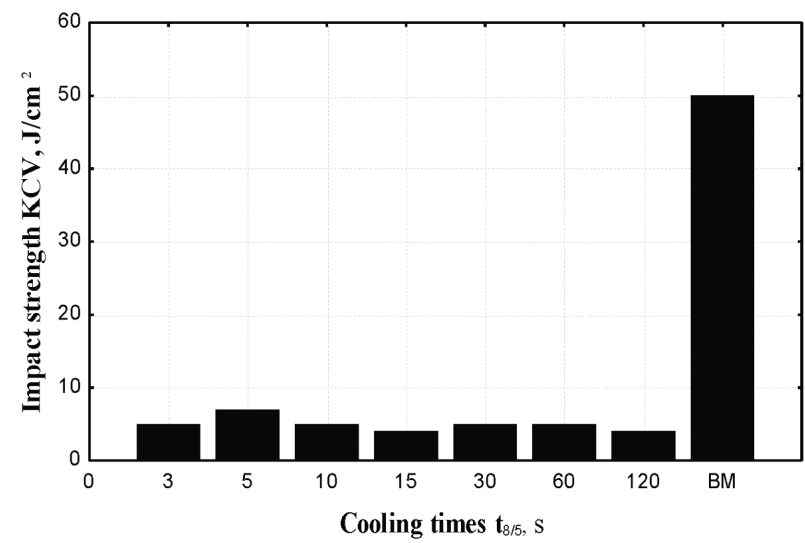

Figure 4: Toughness of simulated HAZ S700MC steel at $-30{ }^{\circ} \mathrm{C}$, cycle temperature $1250{ }^{\circ} \mathrm{C}$

Slika 4: Simulirana žilavost HAZ jekla S700MC pri $-30{ }^{\circ} \mathrm{C}$, temperatura cikla $1250{ }^{\circ} \mathrm{C}$ 

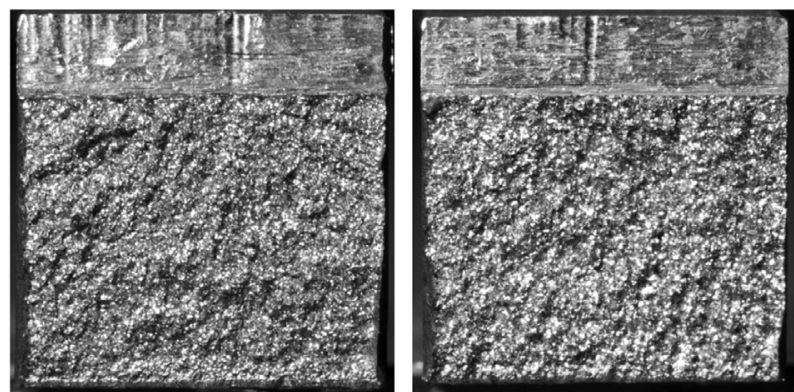

Cooling times $\mathrm{t}_{8 / 5}=5 \mathrm{~s}$

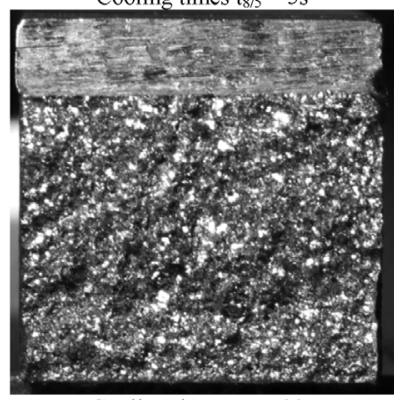

Cooling times $\mathrm{t}_{8 / 5}=30 \mathrm{~s}$

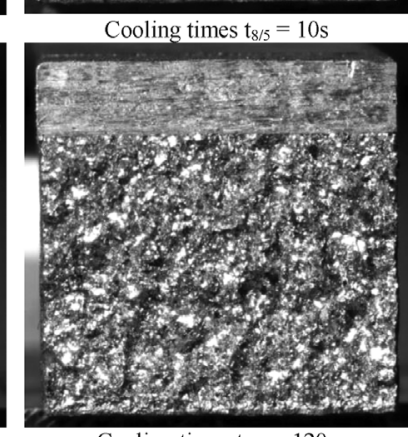

Cooling times $\mathrm{t}_{8 / 5}=120 \mathrm{~s}$

Figure 5: Brittle HAZ fracture of the specimens heated to $1250{ }^{\circ} \mathrm{C}$, after impact test at $-30{ }^{\circ} \mathrm{C}$

Slika 5: Krhek prelom HAZ vzorcev, ogretih na $1250^{\circ} \mathrm{C}$, po udarnem preizkusu na $-30{ }^{\circ} \mathrm{C}$

varying with cross-section. The worst changes were observed in an area heated up to $1300{ }^{\circ} \mathrm{C}$, where the toughness dropped by several $\mathrm{J} / \mathrm{cm}^{2} .{ }^{9}$ Accordingly it was necessary to investigate the effect of cooling time $t_{8 / 5}$ on the microstructure and properties of the HAZ heated up to $1250{ }^{\circ} \mathrm{C}$. For a short cooling time, i.e. below $10 \mathrm{~s}$, bainite mixed with low-carbon martensite is formed in the HAZ. A cooling time in the range $10 \mathrm{~s}$ to $20 \mathrm{~s}$ forms a bainitic-ferritic microstructure closest to the initial microstructure. The further extension of cooling time increases the ferrite content in the microstructure. Cooling times exceeding $100 \mathrm{~s}$ lead to the formation of a ferritic-bainitic structure (Figure 2). After each cooling individual precipitates of several $\mu \mathrm{m}$ size were observed.

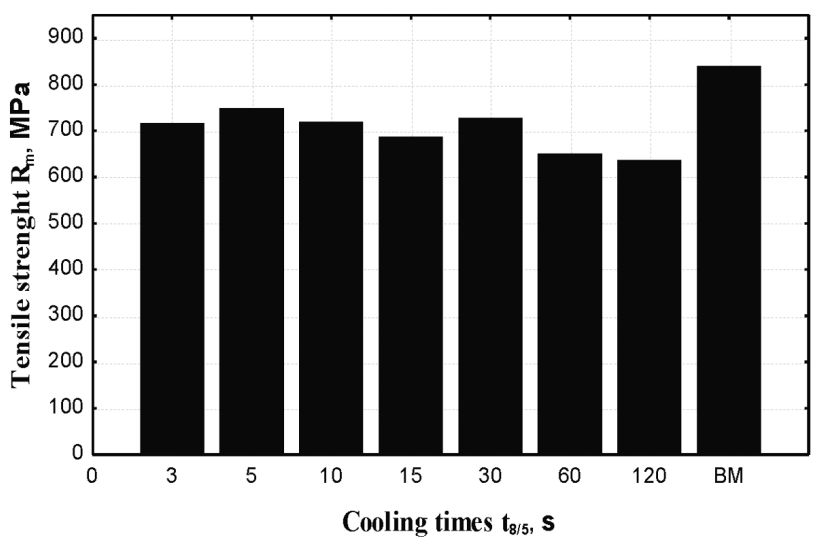

Figure 6: Tensile test of simulated HAZ S700MC steel; cycle temperature of $1250{ }^{\circ} \mathrm{C}$

Slika 6: Natezni preizkus simulirane HAZ jekla S700MC, pri temperature cikla $1250{ }^{\circ} \mathrm{C}$

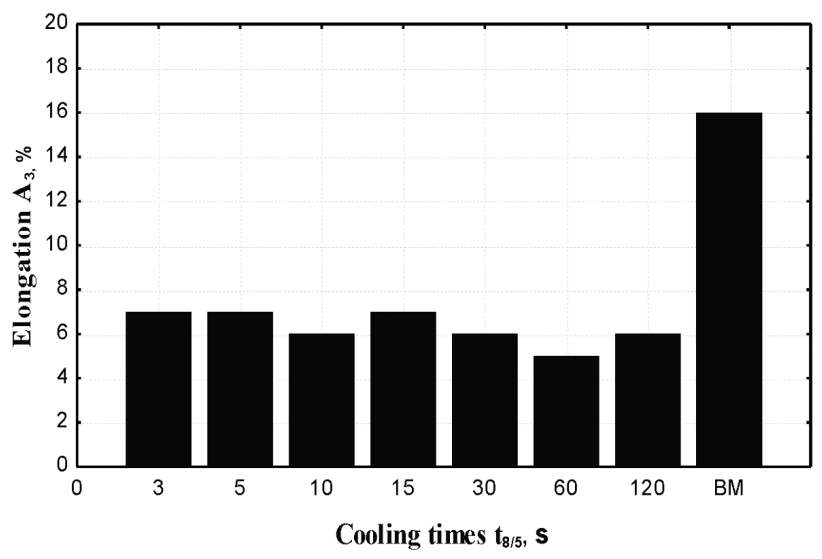

Figure 7: Elongation of the simulated HAZ S700MC steel; cycle temperature of $1250{ }^{\circ} \mathrm{C}$

Slika 7: Raztezki simulirane HAZ jekla S700MC pri temperaturi cikla $1250{ }^{\circ} \mathrm{C}$

The characteristic polygonal shape of the precipitates suggests the precipitates are probably $(\mathrm{Ti}, \mathrm{Nb})(\mathrm{C}, \mathrm{N})$ carbonitrides. The large sizes of the precipitates do not improve steel properties; on the contrary, they could significantly reduce the mechanical and plastic properties of welded joints.

HV1 hardness measurements revealed a slight decrease in the hardness for extended cooling times $t_{8 / 5}$. The hardness in the HAZ area decreased from $265 \mathrm{HV}$ for cooling time of several seconds to $230 \mathrm{HV} 1$ for cooling times longer than $60 \mathrm{~s}$ (Figure 3). Regardless of cooling time, the HAZ area hardness values exceeding $270 \mathrm{HV}$ did not make the area susceptible to cold cracking.

The HAZ toughness tests at $-30{ }^{\circ} \mathrm{C}$ revealed a sharp drop in the mechanical properties with respect to the parent metal, irrespective of cooling time $t_{8 / 5}$ (Figure 4). The thermal cycle temperature of approximately $1250{ }^{\circ} \mathrm{C}$ is responsible for the properties' decrease, especially brittle fractures in impact tests as a result of thermo-mechanical treatment (Figure 5). The toughness of several $\mathrm{J} / \mathrm{cm}^{2}$ is very unsatisfactory for performance of welds with HAZ heated to the highest temperatures

The tensile tests of the round specimens of the steel subjected to thermal cycles at a temperature of $1250{ }^{\circ} \mathrm{C}$ revealed only a slight effect of cooling time $t_{8 / 5}$ on the mechanical properties of the S700MC steel HAZ. In the entire cooling time range of $3 \mathrm{~s}$ to $120 \mathrm{~s}$, the tensile strength of the HAZ was lower than the tensile strength of the parent metal (Figure 6). By extending the cooling time from $3 \mathrm{~s}$ to $120 \mathrm{~s}$, the tensile strength decreased from $720 \mathrm{MPa}$ to $640 \mathrm{MPa}$. This decrease in tensile strength could primarily be ascribed to grain growth in the high-temperature HAZ area. The obtained elongation values of $7 \%$ were significantly lower than the parent metal value of $16 \%$ (Figure 7). 


\section{CONCLUSIONS}

The welding thermal cycle differs significantly from a thermomechanical treatment cycle primarily by the very high heating and cooling rates in the HAZ area, short hold at a maximum temperature and the very frequent coincidence of one or more thermal cycles by multi-layer welding. The analysis of austenite phase transformations by cooling time is one of the elements for steel weldability assessment. For the steel investigated, the of the simulated HAZ (heated up to $1250{ }^{\circ} \mathrm{C}$ ) hardness decreased slightly, by approximately $40 \mathrm{HV}$ with the increase of cooling time from $3 \mathrm{~s}$ to $120 \mathrm{~s}$. Regardless of the cooling time $t_{8 / 5}$, the toughness was very low and diminished to several $\mathrm{J} / \mathrm{cm}^{2}$. The results of the tensile and impact tests, as well as the hardness measurements suggest a secondary role for the austenite transformations in controlling the mechanical and plastic properties of welded joints. The analysis of $\gamma-\alpha$ phase transformations cannot act as the basis for the assessment of weldability in this group of steels.

\section{Acknowledgement}

The study was partially supported by the NOT Innovation Center in Gliwice and Vlassenroot Polska, under the project POIG.01.04.00-24-052/13.

\section{REFERENCES}

${ }^{1}$ C. Lee, H. Shin, K. Park, Evaluation of high strength TMCP steel weld for use in cold regions, Journal of Constructional Steel Research, 74 (2012), 134-139

${ }^{2}$ M. Yurioka, Welding in the World, TMCP steels and their welding, 35/6 (1995), 375-390
${ }^{3}$ J. Górka, Weldability of thermomechanically treated steels having a high yield point, Archives of Metallurgy and Materials, 60/1 (2015), 469-475, doi:10.1515/amm-2015-0076

${ }^{4}$ A. Lisiecki, Welding of Thermomechanically Rolled Fine-Grain Steel by Different Types of Lasers, Archives of Metallurgy and Materials, 59 (2014), 1625-1631, doi:10.2478/amm-2014-0276

${ }^{5}$ M. Opiela, Effect of Thermomechanical Processing on the Microstructure and Mechanical Properties of Nb-Ti-V Microalloyed Steel, Journal of Materials Engineering and Performance, 9 (2014), 3379-3388

${ }^{6}$ A. Lisiecki, Diode laser welding of high yield steel, Proccedings of SPIE, vol. 8703, Laser Technology 2012: Applications of Lasers, 87030S (2013), doi:10.1117/12.2013429

${ }^{7}$ Kurc-Lisiecka A., et al, Analysis of deformation texture in AISI 304 steel sheets, Solid State Phenomena, 203-204 (2013), 105-110, doi:10.4028/www.scientific.net/SSP.203-204.105

${ }^{8}$ A. Grajcar, M. Różański, S. Stano, A. Kowalski, Microstructure characterization of laser-welded Nb-microalloyed silicon-aluminum TRIP steel, Journal of Materials Engineering and Performance, 23/9 (2014), 3400-3406

${ }^{9}$ A. Lisiecki, Welding of titanium alloy by disk laser, Proc. of SPIE, vol. 8703, Laser Technology 2012: Applications of Lasers, 87030T (2013), doi:10.1117/12.2013431

${ }^{10}$ D. Janicki, Disk Laser Welding of Armor Steel, Archives of Metallurgy and Materials, 59 (2014), 1641-1646, doi:10.2478/amm2014-0279

${ }^{11}$ A. Grajcar, M. Różański, M. Kamińska, B. Grzegorczyk, Study on Non-Metallic Inclusions in Laser-Welded TRIP-Aided Nb-Microalloyed Steel, Archives of Metallurgy and Materials, 59 (2014), 1163-1169, doi:10.2478/amm-2014-0203

${ }^{12}$ M. Charleux, W-J. Poole, M. Militzer, Precipitation behavior and its effect on strengthening of an HSLA-Nb/Ti steel, Metallurgical and Materials Transactions A, 32 (2001), 1635-1647

${ }^{13}$ J. Górka, Analysis of simulated welding thermal cycles S700MC using a thermal imaging camera, Advanced Material Research, 1036 (2014), 111-116

${ }^{14}$ Y. Crowther, M. Green, P. Mitchell, The Effect of Vanadium and Niobium on the Properties and Microstructure of the Intercritically Reheated CoarseGrained Heat Affected Zone in Low Carbon Microalloyed Steels, ISIJ International, 41 (2001), 46-55 